\title{
CONTRACTS FOR THE BENEFIT OF THIRD PERSONS IN CONNECTICUT
}

\author{
Arthur L. CORBin \\ Professor of Law, Yale University
}

Can a person for whose benefit a contract is made, but who is not himself the promisee and who did not give any consideration, maintain any form of action against the promisor for breach of contract? Does society recognize that he has any "rights" and enforce them at his request? In a previous article," these questions were unhesitatingly answered in the affirmative, recognizing, however, that there was a good deal of confusion in the law, and that in certain jurisdictions the third person's rights were not recognized in all cases. Among these jurisdictions were England, Massachusetts, Michigan, and Connecticut.

In England, however, it was possible to cite six cases in which the third person had been held in equity to have enforceable rights. And in a recent case $^{2}$ the House of Lords has sustained an ordinary law action, equivalent to the common-law action of assumpsit; but the

${ }^{1}$ (I9I8) 27 Yale Law Journal, I008; See also Anson, Contract (Corbin's ed. I9I9) ch. IX.

${ }^{2}$ Les Affreteurs v. Walford [I9I9, H. L.] A. C. 80I. A charterparty contained the following provision: "A commission of three per cent .... is due to Leopold Walford on signing this charter (ship lost or not lost)." Walford was a ship broker who had negotiated the contract between the owner and the charterer, and that contract provided that his commission was to be paid by the owner. This action was by Walford against the owner, and by stipulation the action was treated as if the charterers were added as co-plaintiffs. Judgment was given in favor of Walford, and the owner was not allowed to prove-contrary to the terms of the contract-a custom that the broker's commission should be dependent on the earning of freight.

Lord Birkenhead, L. C., at p. 805, said: "A charterparty is, of course, a contract between owners and charterers, and it is elementary that, so far as the brokers are concerned, it is res inter alios acta .... (but) it was decided nearly seventy years ago .... that charterers can sue under an agreement of this character as trustees for the broker." Lord Finlay, at p. 810, said: "We must regard the charterer as having entered into that bargain in the interests of the broker and as a trustee for the broker." Lord Wrenbury, at p. 813, said: "We have here to do with a contract between two parties reserving a benefit to a third." The contract contained no words describing the charterer as trustee or agent for the broker. It is a curious fiction that turns one of the contracting principals into an agent and trustee for the broker who was himself in fact a fiduciary and agent in the transaction. This agency fiction was one of the grounds of decision given in Lawrence $v$. Fox (I859) 20 N. Y. 268 . It was indeed a "very sensible arrangement" to dispense with the charterer as a co-plaintiff, even though he himself did not agree to such a dispensation, for he had no pecuniary interest and could not have controlled the action had he been joined as plaintiff. 
court was able to point to a few special facts so that it did not purport to overrule previous cases.

In Massachusetts, the court originally had laid down the general rule that the third person has enforceable rights, but later had restricted it to a few exceptional classes of cases, and finally was believed to have abandoned the rule entirely. There are, however, at least a half dozen recent cases that sustain an action brought by the third party, giving reasons and making distinctions that are not very convincing. ${ }^{3}$

In Michigan very recently the court decided such a case in favor of the third person, perhaps without observing that it was reversing its past policy. It granted a rehearing later, but sustained its former decision, finding a fictitious privity between the plaintiff and the defendant."

A review of about fifty Connecticut decisions shows that it is even more unsafe to classify Connecticut as denying "rights" to the third person than it is in the case of England, Massachusetts, or Michigan. Not all of these cases will be mentioned in this article; nor will it discuss

- in any detail distinctions between common law and equity, or the differences, if there are any, between legal rights and equitable rights, socalled. The lawyer's first necessity is to be able to tell his clients whether or not they have any rights at all and what they are, whether or not privity of contract is required to create rights, whether or not a "stranger to the consideration" has any rights.

The cases in which the question of a third person's rights has arisen fall into two general classes: $I$. Cases where the third person is the only person who will benefit by the agreed performance-he is a Sole Beneficiary. II. Cases where the promisee obtains the promise in order to bring about the settlement of a debt that he owes to the third person; where, therefore, there are two persons who will benefit by the agreed performance, the promisee being one and his creditor being the other. In these cases the third person will be called a Creditor-Beneficiary.

Examples of class I, where the third person is the sole beneficiary, are old line life insurance policies, fraternal benefit policies, a devise to $A$ on condition that he pay a sum to $B$, and money paid to $A$ to be delivered by him to $B$.

Examples of class II, where the third person is a creditor-beneficiary, are: a debtor conveys his property to the defendant who promises to pay off creditors; a mortgagor conveys his equity to a grantee who assumes

\footnotetext{
' Gardner v. Denison (1914) 217 Mass. 492, 105 N. E. 359; Paper Stock D. Co. v. Boston D. Co. (1888) I47 Mass. 318, r7 N. E. 554 (licensor of patent collected royalty from assignee of licensee); Goulding $v$. Phimey (I920) 234 Mass. 4II, I25 N. E. 703 (restrictive covenants in a deed create irrevocable rights in other lot owners); Collins v. Collins (19I2) $2 \mathrm{I} 2$ Mass. I3I, 98 N. E. 588 (heir gets specific performance of antenuptial contract made by ancestor); Palmer Sav. Bk. v. Ins. Co. (I896) I66 Mass. 189, 44 N. E. 2II; Forbes $v$. Thorpe (I9II) 209 Mass. 570. 95 N. E. 955.

'Preston v. Preston (1919) 205 Mich. 646, 172 N. W. 371, I75 N. W. 266.
} 
payment of the mortgage debt; a building contractor gives a surety bond conditioned on the payment of laborers; a fire insurance policy is made payable to a mortgagee as his interest may appear; a sheriff gives a bond to the state conditioned on paying damages suffered by any person; A buys one of a group of lots, entering into restrictive covenants for the benefit of other lot owners.

\section{EARLY CASES}

A few early cases will first be reviewed without respect to the class to which they belong, because they are cited in many of the later cases of all classes.

The earliest of these cases is Sanford $v$. Sanford. ${ }^{5}$ The plaintiff sued in debt on a bond given by the defendants to the town of Woodbridge, conditioned on the support of the plaintiff and the indemnification of the town against having to support her. It was held that the action would not lie. The decision is sound, because on nonfulfilment of the condition the penalty became payable to the town and not to the plaintiff, and the town was the only party to whom a money debt was due. Had the plaintiff sued in assumpsit for damages for failure to support her, the court would have had to determine whether or not the "condition" of the bond amounted to a promise to perform in accordance with it. It is now generally held that such condition does amount to a promise and does create a legal duty to somebody. This is rendered the more certain because the exact penalty of the bond is now seldom collectible by action, the bond being regarded as an undertaking to perform the condition, for breach of which damages are collectible. If the bond creates such a legal duty, it might in this case well be held to be merely a duty to the town, the bond being merely to indemnify the town as sole beneficiary as well as promisee and not at all for the benefit of the plaintiff.

In Crocker v. Higgins, ${ }^{6}$ one Wadsworth conveyed land to the defendant for half its value, the latter orally promising to give a life lease of the land to the plaintiff, a third person. The plaintiff brought a bill in equity for specific performance, and obtained a decree. The court held that Wadsworth was not a necessary party, having no beneficial interest; and also that the facts operated to create a right in the plaintiff. The court did not put this on the ground that there was a trust, although perhaps it might have done so; and it did not specify whether the plaintiff's right should be regarded as legal or equitable. Chief Justice Hosmer said :

"Even in a court of law, where the question is embarrassed by considerations somewhat artificial and technical, it is now established that a

( 1807, Conn.) 2 Day, 559.

- (1829) 7 Conn. 342. 
third person may maintain a suit on a parol promise made for his benefit, although he is not a party to the contract."?

Observe that in this case the plaintiff was the sole beneficiary.

- In Treat $v$. Stanton, money had been left in trust to the plaintiff for certain purposes. The plaintiff turned this money over to the defendant, on the latter's promise to pay it to the beneficiaries of the trust on the order of the plaintiff. The court held that the plaintiff, as promisee, could maintain assumpsit for breach of this promise, although the defendant argued that only the berieficiaries should be allowed to sue. The court does not hold that the beneficiaries could not sue at law, although the fact that they were beneficiaries of a trust, as well as beneficiaries of the express contract with the defendant, would probably have led the court in I84I to declare that their only remedy was in equity. But the court quoted with approval Chitty's statement that "the party for whose sole benefit it is evidently made may sue thereon in his own name, although the engagement be not directly to or with him." It is evidently the court's opinion that a sole beneficiary can sue although other beneficiaries cannot; but the actual decision is merely that the promisee can sue.

In Steene v. Aylesworth, ${ }^{9}$ a debtor had assigned certain property to the defendant who promised to sell it and apply the proceeds to pay creditors. Later the plaintiff became the assignee in bankruptcy of the debtor, and now sues the defendant in assumpsit for breach of the promise. The defendant argued that the creditors for whose benefit the promise was made were the only parties who could sue. Chief Justice Williams said:

"It is true, that after great diversity of opinion among the judges,. it is now settled that where a promise is made to one man for the benefit of another, the latter may sustain a suit upon that promise. But it does not follow from this that the promisee himself could not sustain a suit."

And the court held that this action lay in favor of the assignee of the promisee.

\section{SOLE BENEFICIARIES}

Not a single Connecticut case has been discovered denying that a sole beneficiary has a legal right enforceable in a contract action, although one case erroneously fails to apply the admitted rule. Thus, where a devise, given on condition that a certain sum be paid to a benficiary, is accepted by the devisee, the latter is a debtor of the beneficiary irrespective of the value of the devise. ${ }^{10}$. In Olmstead $v$. Brush, ${ }^{11}$ the devisee

\footnotetext{
"The court cited Dutton v. Poole (1677, K. B.) 2 Lev. 210; Schemerhorn v. $V$ anderheyden (1806, N. Y.) I John. I40; and Arnold v. Lyman (I821) I7 Mass. 400.

${ }^{8}$ (I84x) I4 Conn. 445.

(I846) I8 Conn. 244.

${ }^{10}$ See Anson, Contract (Corbin's ed. 1919) sec. 286.

${ }^{11}$ (1858) 27 Conn. 530.
} 
was also the executor of the will. The court held that the devisee's failure to pay was not a breach of his duty, as executor, and that the plaintiff (the beneficiary) could not maintain an action on the executor's bond. It was the devisee's personal debt to the plaintiff. The same principle applies where a grant is made by a deed poll on condition that the grantee pay money to a third person. As to this the court said:

"Not that the grantee covenants to do it, for the words are the words of the grantor, but if the grantee accepts the deed he assents to the condition in it, and becomes liable on an implied assumpsit to keep and perform it."

And the court further quotes the opinion in Parish v. Whitney: ${ }^{\mathbf{2}}$

"It is quite clear it is not a reservation out of the estate granted. The whole estate passed by the deed. It is not a condition upon which the estate is to be held, and for breach of which an entry might be made by the grantor. It is not declared to be a condition, nor is any right of entry reserved. It is not a covenant, running with the land or otherwise. It is but a personal agreement of the grantee made as a part of the consideration of the grant and evidenced by his acceptance of the deed, which may bind him and his legal representatives, but does not affect his estate."

Of course, it has never occurred to any one that the beneficiary of an old line life insurance policy cannot sue the insurance company. Not only does the beneficiary get a legal right, even though he is not a party to the policy and has never paid the premiums, but it is even held that he has an.immunity as well as a right, in that the insured has no power to change the beneficiary unless such power is clearly reserved in the policy. ${ }^{13}$

In some respects a policy in a fraternal benefit association is different from an old line policy. There are several statutory provisions. Sec. $4 \mathrm{I} 86$, Gen. Sts. r9r8, provides what "shall constitute the agreement between the society and the member"; but nothing is said about any agreement between the society and the beneficiary, and there is no section that declares that the beneficiary can maintain suit. Sec. 4184 provides that "each member shall have the right to designate his beneficiary, and to have the same changed in accordance with the laws, rules, or regulations of the society, and no beneficiary shall have or obtain any vested interest in said benefit until same has become due and payable upon the death of said member." In other words, this means that the member shall have the legal power of naming and of changing his beneficiary, and that the latter shall have no immunity from change until the member is dead. Prior thereto he has what the court calls merely a "revocable, contingent expectation not amounting to a property right."14

12 (1855, Mass.) 3 Gray, 516.

${ }^{13}$ See Vance, The Beneficiary's Interest in a Life Insurance Policy (1922) 31 YaIE Law JournaL, 343.

${ }^{11}$ This was said in Order of Scottish Clans v. Reich (1916) 90 Conn. 5II, 514, 
The word "expectation" is not of much service, and it makes trouble for the court in a later case. The better description is to say that the beneficiary has a future, conditional right, with a liability to its destruction by the member. The right is conditional both on the beneficiary's outliving the member and on the member's not exercising his power of change.

However we may regard the legal relations of the parties before the member's death, it is certain that the beneficiary has a legal right against the society after the member's death. If, prior 'to the member's death, the beneficiary has no inheritable right, neither has the promisee, the member himself. This is shown by the decision in Estes v. Local Union of United Brotherhood of Carpenters and Joiners. ${ }^{15}$ John Bickford was a member of the union, and its by-laws provided for a funeral benefit of $\$ 100$ to be paid to a person to be named by the member. $\mathrm{He}$ named his sister, the plaintiff; but the defendant had no notice of this until after his death. After such notice, however, the defendant paid $\$$ Ioo to Bickford's widow. The plaintiff, as the actually appointed beneficiary, sued for the $\$ 100$ that the society had promised Bickford to pay, and got judgment. Chief Justice Prentice said:

"Bickford, while living, had no property in the benefit payment, or interest in it other than the power to designate a beneficiary to receive it, and upon his death no right to it passed to his estate."

In Supreme Colony, United Order of the Pilgrim Fathers v. Towme, ${ }^{17}$ one Hanaford, a member, designated his wife as beneficiary of a death benefit. She died first, and he named no one else. Claim to the benefit was made by her administrator and by his administrator. In an interpleader suit, the court held that neither one was entitled, for the reasons given above. Neither the member nor his beneficiary had a descendable property interest. As to the member, the court said:

"A mere power of appointment is not an asset in the donee of the power and conveys no title to or interest in the property conveyed, and, unexercised by the donee prior to his death, becomes wholly unoperative. The insured member can neither assign, transfer, pledge, nor bequeath the benefit. Nor does it descend to his heirs."18

If no beneficiary is designated, the society keeps the money. But here the society made no claim and asked the court to determine who was

97 At1. 863,864 , holding that where the beneficiary dies before the member does, the beneficiary's administrator gets nothing after the member's death. See also Supreme Colony v. Towne (I914) 87 Conn. 644, 648, 89 Atl. 264, 266.

${ }^{15}$ (Igr6) 90 Conn. 426, 97 Atl. 326.

${ }^{10}$ See to the same effect Masonic M. B. Assoc. v. Tolles (I889) 70 Conn. 537, 40 Atl. 448.

17 (I9r3) 87 Conn. 644, 89 Atl. 264.

${ }^{18}$ See also Cook v. Improved Order Heptasophs (I909) 202 Mass. 85,88 N. E. 584; Hellenberg v. Independent Order of B'nai Berith (1884) 94 N. Y. 580; Eastman 2. Provident M. B. Assoc. (1883) 62 N. H. 555 . 
entitled. The only relative was a half-brother. Judgment was given that the defendant pay the half-brother (because he might have been made a beneficiary).

It thus appears to be well established that the beneficiary of a fraternal society policy has an enforceable legal right after the member's death. The member, himself, has contract rights, but they do not include a right to payment that goes to his administrator.

The next case to be considered is Baxter $v$. Camp. ${ }^{19}$ The defendant, being indebted to his wife, gave her a signed paper promising to pay $\$ 800$ to the plaintiff, the wife's son by a former marriage. The money was to be paid after the wife's death, to the plaintiff if he should survive the wife, otherwise to the wife's heirs. This paper the wife afterwards delivered to the plaintiff, saying that the defendant would pay it. The wife died, and the defendant refused to pay. The court held that the plaintiff could not maintain suit. The court said that the general rule is that only a party to a contract can sue, but enumerated four exceptions: ( $\mathrm{I}$ ) where the promisee is acting as agent of the third party; (2) where the promise is part of a family or marriage settlement "under which a direct benefit is secured to children or other near relatives. Here the unity of the family has been taken into account, and the consideration of marriage deemed to extend to its issue"; (3) promises "made to one man for the direct, sole, and exclusive benefit of another. Thus $C$ may sue for money paid to $A$ for his use by $B$, when it was part of their agreement that the payment and its object should be communicated to him. Here $A$ is in the position of a forwarding agent for $\mathrm{C}$, and when the latter is informed of the transaction and assents to it, this may be properly treated as a ratification"; (4) bailments in trust for a third party "that cannot be brought under the law of principal and agent," an "equitable action" being maintainable. The court adds :

"But the remedy can never be pressed beyond the right, and can seldom, if ever, extend to a stranger to the consideration, who is not in some relation of privity with the nominal promisee. ${ }^{20}$ Unguarded expressions are to be found in some of the earlier opinions of this court, which countenance the broad proposition that where a promise is made to one man for the benefit of another, the latter may sustain a suit upon that promise; but no such doctrine has ever been applied to govern our determination of a cause." 21

The court then proceeds to hold that this promise was not "for the

39 (I898) 7I Conn. 245, 4I At1. 803.

${ }^{20}$ Here the court cited Treat v. Stanton (184I) I4 Conn. 445; Woodbury Sav. Bk. v. Charter Oak Ins. Co. (I860) 29 Conn. 374; Clapp v. Lawton (1862) $3 \mathrm{I}$ Conn. 95; Meech v. Ensign (I88I) 49 Conn. I9I; Nat'l. Bank v. Grand Lodge (I878) 98 U. S. I23; Exchange Bank v. Rice (I87I) I07 Mass. 37; Tweddle v. Atkinuson (186I, Q. B.) I B. \& S. 393; Pollock, Contracts, ch. V.

${ }^{2}$ Here citing Crocker v. Higgins (1829) 7 Conn. 342; Steene v. Aylesworth (I846) I8 Conn. 244 . 
direct, sole and exclusive benefit of the plaintiff, nor yet as in the nature of a family settlement. Its immediate object was to protect the interests of his mother. It was the adjustment of an unsettled account, followed by provisions designed to serve the purpose of a testamentary disposition." The court said that the personal representative of the wife was the only person who could sue "at law," and that if the defendant could maintain an equitable action, the wife's personal representative would be an "indispensable party."

Very likely the court's order for a new trial can be sustained on other grounds given in the court's opinion; but, with great respect, it is submitted that all of the foregoing reasons must be disapproved, not only in the light of generally prevailing law, but in the light of the admissions of the court in this very opinion and of other Connecticut cases. . It is not at all apparent why this should not be regarded as a case of a "family settlement," the beneficiary being the promisee's own son, and the promisor being the promisee's own husband. It seems equally certain that the defendant's promise was made "for the direct, sole and exclusive benefit of the plaintiff," provided he outlived the promisee, his mother. This condition was in fact fulfilled, and so the provision for the benefit of other persons as the promisee's heirs becomes immaterial. In no case would performance be a financial benefit to the promisee, since performance was in any case to be after her death.

In addition, the plaintiff was not only the sole beneficiary-he was also an assignee of the promisee. Her delivery of the document to the plaintiff should be held to be an executed assignment by way of gift; and the Connecticut court has expressly held, in both earlier and later cases, that a beneficiary who holds an assignment from the promisee can maintain suit. ${ }^{22}$

This case, it must be remembered, was brought under the Practice Act. If either the ancient Common Law or the ancient Equity would have enforced the defendant's duty to the plaintiff, the court should have done so in this case. There was no more reason for denying the plaintiff a remedy than in the case of fraternal benefit or other insurance policies, and no more reason for holding that the wife's administrator was "an indispensable party" than that the administrator of the insured is an indispensable party. The enforcement of the contract would require no payment to such administrator.

\section{CREDITOR-BENEFICIARIES}

Where a valid contract is made for the sole and exclusive benefit of a third person, it may be asserted with confidence, in spite of Baxter $v$.

\footnotetext{
${ }^{2}$ Hyland v. Crofut (I9I3) 87 Conn. 49, 86 Atl. 753; Foster v. Atwater (1875) 42 Conn. 244; Bassett v. Bradley (I880) 48 Conn. 224; Reed v. Paul (I88I) I3I Mass. 129. In such case the beneficiary sues in his own name; and his recovery is the amount promised him, not the amount the promisee might have recovered.
} 
Camp, that Connecticut law gives such third person an enforceable legal right. It is not so easy to make this assertion in the case of a third person who is not the sole beneficiary. We must observe in the first place that a third person who is not the sole beneficiary may not be a beneficiary at all. If the contracting parties did not intend to create any rights in the third person, there is much less reason for holding that the contract creates such rights. He may already have various rights as a creditor or otherwise, but in this respect he is no different from any stranger. Granting that it is possible for a beneficiary to be given new rights by the contract, the question must still be answered, who is a beneficiary?

First, if a mortgagor conveys his equity to a grantee who assumes the mortgage debt, is the holder of the mortgage note a beneficiary with an enforceable right?

\section{MORTGAGEE-BENEFICIARIES}

By Gen. Sts. I9I8, sec. 56Io, it is now provided that if the mortgagor conveys his equity to a grantee who assumes the debt, the mortgagee may sue such grantee "in his own name upon such promise, without obtaining an assignment thereof from the grantor of said premises." This provision became law by act of legislature in I88I, and was literally embodied in the revisions of 1888 , I902, and I9I8.

Prior to this statute, it had been held in two cases $^{23}$ that a mortgagee could sue such a grantee if the mortgagee had obtained an assignment from the mortgagor (the promisee). In these cases not much was said about the assignment except to hold that the mortgagor, as promisee, had an interest to assign.

In I88I, the court decided the important case of Meech $v$. Ensign ${ }^{24}$ Here, after foreclosure, the holder of the mortgage note sued for a deficiency judgment against the assuming grantee of the equity of redemption. The plaintiff held no assignment from the mortgagor; instead, the latter had expressly released the defendant. Justice.Carpenter, in an excellent opinion, reviewed the authorities fully, explained the principles involved, and held that the plaintiff had no right of action. To the supposedly general rule that a stranger to the contract cannot sue, the court admitted of several exceptions: (I) cases where assets are in the defendant's hands to pay to the plaintiff, the action then being for money had and received, "not on a promise to the debtor but on an implied promise to the creditor;" (2) cases "where the contract has for its object a benefit to a third party and is made with that intent."

The court expressly approved of both of these exceptions, and apparently disapproved of the English and Massachusetts cases that have

${ }^{23}$ Foster v. Atwater (1875) 42 Conn. 244, and Bassett v. Bradley (I880) 48 Conn. 224.

${ }^{24}$ (I88I) 49 Conn. I9I. 
denied them. And it held that the plaintiff was not entitled to recover, solely on the ground that the case fell within neither exception. The defendant had no "assets," and the contract was not made for the plaintiff's benefit. Several paragraphs of the opinion are worth quoting in full.

"What was the transaction? It was not a sale of a piece of land for a fixed price, equal to the value of the land, so as to create a debt for that sum; but was simply a sale of the equity of redemption. The distinction between land, unincumbered, and the equity of redemption, is obvious enough, and is an important one, as on it depend in a great degree the rights and obligations of the parties. The defendant purchased the equity of redemption. The finding is that the mortgagor 'conveyed to the defendant said real estate subject to said mortgage.' So that the only debt brought into existence by -the transaction was the price agreed to be paid for the equity of redemption. The mere purchase raised no debt to the mortgagor which the defendant was to discharge by paying the incumbrance. By the contract of assumption he obliged himself to the mortgagor to pay the mortgage debt. Whether that raised any personal obligation to the mortgagee is the question in the case. If the probable intention of the parties is to govern, it is difficult to find any such liability in the transaction. The mortgagee was not a party to it, no part of the consideration moved from him, and he was in no worse condition because of it. He still had the security of the land and the personal responsibility of the mortgagor, and that is all he contracted for or required. The parties contracted with reference to their own interests, not his; to benefit themselves, not him. He had no legal or equitable interest in the contract and there is no room for the presumption that it was intended for his benefit.

"There was no agency express or implied. The mortgagor would doubtless be surprised at the suggestion, should it be made, that he was acting as the agent of the mortgagee. There was no substitution or novation, for that requires three parties, and here were only two; besides the original debtor was not discharged.

"It was not the object of the parties to give the mortgagee additional security; and to interpret it in that sense is to give it a force and meaning never contemplated by the parties, and is, in effect making a contract for them. The only contract which they made was simply this- the defendant agreed that he would pay the mortgagor's debt. The promisee alone had the legal and equitable interest. It follows that he alone can enforce it unless he imparts that right to others. That he may sue will not be disputed. If the mortgagee has that right by force of the contract, then two persons wholly independent of each other have an equal right. If either may sue both may, and a suit by one will not abate or bar a suit by the other; and a discharge by one for any cause short of a fulfillment will not discharge the contract. Thus the promisor may be harassed with two suits at the same time on the same contract, and if he would compromise with the promisee he must obtain the consent of a stranger. If this is the law it is an anomaly, for another instance of the kind is hardly to be found in the whole range of jurisprudence.

"We are aware that there are decisions from courts of the highest authority, and whose opinions are entitled to the highest respect, which hold that the creditor may sue on such contracts; perhaps it is not too 
much to say that the prevailing current of authority in this country is in that direction; but believing as we do that they are not founded in good reason or sound policy we cannot accept them as law. The question is an open one in this state, and principle, rather than precedents not founded in principle, should determine it."

The statute of I88I has nullified this decision, but has not affected its approval of the rule giving a right of action to one for whose benefit a contract is made by two others. The statute indicates either that in such cases the grantor and grantee of the equity must intend that the mortgagee shall have an enforceable right against the grantee, or that it is the public will that he shall have such a right in the absence of such an intention. It is certainly the almost universal rule, and there is little doubt that it carries out the general intention of the contracting parties. The mortgagor wishes to drop out of the transaction, and no doubt often erroneously supposes that he is no longer bound to pay the debt. The grantee in general supposes that he has become a debtor in place of his grantor. This mutual intention is best carried out by letting the mortgagee sue the grantee directly. Not often will he be sued by both his promisee (the mortgagor) and the mortgagee; and if he fears a second suit, he can under our modern procedure cause the other possible complainant to be joined in the first action.

The validity of the foregoing statute was attacked in Colchester Sav. Bank v. Brozem; ${ }^{25}$ but the court sustained its validity, and held that it enabled the mortgagee to sue not only the immediate grantee of the mortgagor, but also any subsequent grantee, in case each grantee in the chain had assumed the debt. Judge Prentice said:

"It is an emphatic commentary upon this contention that so many of our States have, independently of any statute, held the law to be as our statute defines it."

The principles applicable in favor of a mortgagee-beneficiary are applicable to any other creditor-beneficiary. If the statutory reversal of Meech v. Ensign is sound in policy, and if a mortgagee ought to be given an additional security even though he was not primarily intended as the beneficiary of the contract, so should other creditor-beneficiaries be given a remedy. However, it appears that they cannot yet maintain an ordinary contract action. They have rights that are recognized, but they are enforced only when the complainant makes use of equitable terminology and procedure.

In Clapp $\dot{v}$. Lawton, ${ }^{26}$ the firm of Faulkner \& Wright dissolved and was succeeded by the firm of Lawton \& Wright, all the property and accounts being conveyed to the new firm; and the new firm assumed

\footnotetext{
${ }^{25}$ (I902) 75 Conn: 69, 52 At1. 316. An assumption clause in the deed of conveyance is not conclusive evidence that the grantee did in fact assume the debt. Haskins v. Young (I915) 89 Conn. 66, 92 Atl. 877; Raffel v. Clark (1913) 87 Conn. 567,89 Att. 184.

${ }^{20}$ (1862) 31 Conn. 95.
} 
payment of the debts of the old firm. The plaintiff; as one of the old creditors, sued the new firm in assumpsit on this promise. It was held that the action would not lie. ${ }^{27}$ The plaintiff claimed a right, however, on the ground that assets had come into the defendant's hands in which he, as creditor, had an equity, and that this should sustain the count for money had and received. The court held that this was not a proper form of action to enforce this admitted equity, because other creditors had a like interest, and it did not appear that the assets made available were equal to the debts to be paid. "Although we should have been better pleased to have come to a different result, we think this objection must prevail." The plaintiff's remedy was said to be in equity. The defendants were regarded merely as trustees of the assets for the benefit of creditors, although this was not their agreement with the old firm.

In Lamkin v. Baldwin, etc. Co. ${ }^{28}$ partnership assets were transferred to the defendant corporation, and it promised the partner so transferring to pay the debts of the firm. In a receivership suit against the corporation, Judge Baldwin said: "No right of action, at common law, was given to the creditors whom it was designed to secure." ${ }^{29}$ But he proceeded to hold that the claims of these creditors should be allowed against the corporation in this receivership action to rank after corporation creditors who became such on the faith of the property conveyed. Here, it will be observed, there were assets in the defendant's hands; but the court does not limit the rights of the partnership creditors to the value of these assets. These creditors have an enforceable right against the corporation based upon its assumption of the debts.

In Morgan v. The Randolph \& Clowes Co., ${ }^{30}$ the plaintiff was a creditor of a partnership composed of R. \& C. This partnership was dissolved, all of the property was conveyed to the defendant corporation, and it promised in retúrn to pay all existing debts of the partnership and to save the partners harmless therefrom. The plaintiff sued to enforce this promise, asking "legal relief only." A demurrer to the complaint was sustained. While admitting that the general rule elsewhere was otherwise, the court said that in Connecticut "where A simply agrees with $B$, upon a valid consideration, to assume and pay $B$ 's debts and save $B$ harmless therefrom, $C$, a creditor of $B$, cannot maintain an action at law against $A$ for his refusal to pay the debt due from $B$ to C." 31

\footnotetext{
${ }^{27}$ The court cites and follows Treat $v$. Stanton (I84I) I4 Conn. 445.

${ }_{23}^{28}$ (1899) 72 Conn. 57, 43 At1. 593, ro42.

${ }^{20}$ Citing Clapp v. Lawoton (I862) 3I Conn. 95; Baxter v. Camp (1898) 7I Conn. 245, 4I At1. 803.

${ }^{20}$ (1900) 73 Conn. 396, 47 At1. 658.

${ }^{31}$ The court cites Treat v. Stanton (184I) I4 Conn. 445; Clapp v. Lawton (I882) 3I Conn. 95; Meech v. Ensign (I88I) 49 Conn. I9I; Baxter v. Camp (1898) 7x Conn. 245, 4I At1. 803; Lamkin v. Baldzwin, etc. Co. (1899) 72 Conn. 57, 43 Atl. 593, 1042.
} 
The decision was evidently under the influence of the decision in Baxter v. Camp. It was said to fall within none of the exceptions in that case. Judge Torrance says that the contract was made solely for the benefit of the promisees, and that there was no intention to create any legal right in the plaintiff against the defendant. The plaintiff claimed no special "equity" in the assets.

Atwood v. Burpee ${ }^{32}$ is another case influenced by Baxter v. Camp, and closely follawing Morgan v. Randolph \& Clowes Co. both in point of time and in manner of reasoning. The defendant was executor of $T$., and promised Mrs. T. to collect insurance on a policy of which she was beneficiary and out of money thus obtained to pay a sum due to the plaintiff, who had presented a claim against the estate of $T$. The promisee, Mrs. T., was interested, as a distributee, in seeing her husband's debts paid. The plaintiff was a creditor of the estate, although not of Mrs. T. The court held that the plaintiff could not maintain suit, remarking "this is not an action for the enforcement of an equitable right, but of an alleged legal right." As in the Morgan case, the court said that the plaintiff was not intended as a beneficiary: "the parties to the contract could not have intended to give to the plaintiff a right of action upon it against the defendant." If this was the fact, the courts of other states would generally agree with the decision; but other courts do not agree that "the mere fact that one would receive a direct benefit from the performance of a contract, to which he is not a party, does not enable him to maintain an action at law upon it." It is obvious that the plaintiff might possibly have won if he had claimed an "equitable" right and had called his civil action a bill in equity.

In Barber v. Internat'l Co. of Mexico, ${ }^{33}$ the defendant company conveyed its assets to an English corporation, and the latter promised to pay debts of the defendant. The plaintiff was a creditor and had tried to collect from the corporation in England, but had failed. $\mathrm{He}$ now asked that a receiver be appointed on behalf of the plaintiff and other creditors, so that the receiver might enforce the defendant's contract with the English corporation. The defendant was insolvent, but the plaintiff had no judgment against it. Judge Baldwin said that this was not a creditor's bill, nor a winding-up proceeding. He sustained the complaint on demurrer. Why did he do this? Because the transaction between the two corporations created rights in the plaintiff against them both. He said:

"The obligation runs to the defendant, but it creates a security which, while directly for its benefit, is indirectly for the benefit of its creditors. .... Their rights against this third party (the English corporation) are wholly derived from the contract. They have no lien on the assets transferred. A release by the defendant to the English company would effectually discharge its legal obligation. It would be clearly inequitable under present circumstances to give such a release. Any creditor could

\footnotetext{
(x904) 77 Conn. 42, 58 Atl. 237. $\quad$ (I90I) 73 Conn. 587, 48 Atl. 758.
} 
ask for an injunction to prevent it. A claim for that relief might well have been made in the present action. But the remedy of an injunction, like that of the appointment of a receiver, presupposes the existence of some actionable right to preserve or enforce which an injunction or a receivership is necessary. Such a right may be a legal one .... but in the present case it is purely equitable, since the legal remedy by reason of the assumption of the debt due to the plaintiff by the English company .... belongs to the defendant only. To the extent of the assets received .... the defendant's creditors .... may have an equity enforceable against the English company, to establish a charge upon the funds, or otherwise secure its performance of the contract made, in a certain sense, for their benefit. But they also have an equity enforceable against the defendant to compel it to lend its aid and do its part towards working out their beneficial rights. .... The plaintiff's complaint was properly adjudged sufficient. It is in substance, an appeal to a court of equity to secure the enforcement of a contractual right which the defendant holds in what .... may fairly be regarded as a fiduciary. capacity, and which it collusively refuses to enforce for the benefit of those who are equitably entitled to claim its benefits."

It will be observed from these cases that where a debtor turns over his assets to the defendant and the latter promises to pay creditors, such creditors are regarded as beneficiaries of the contract. They cannot maintain assumpsit, or its equivalent under the Practice Act, against the promisor; but an enforceable right against him is recognized and the creditors can enforce it if they explain their claim properly and ask for the sort of remedy formerly given by the Chancery instead of the courts of Common Law. Because of the defendant's promise to the debtor and the receipt of his assets, the defendant may be treated as a trustee of those assets for the named creditors, although he agreed not to act as a trustee but to pay out of his own pocket. And the Barber case indicates that by means of complex receivership proceedings, the promisor can be compelled to perform as he promised or to pay damages. When the receiver sues the promisor and collects judgment, he will no doubt be required to hold the sum collected as trustee for the named creditors. If this is so, the creditors are the real party in interest and should be allowed to bring a direct and simple action against the promisor, making the promisee a formal party to the contract if this seems for any reason desirable.

INSURANCE POLICIES PAYABLE TO THE MORTGAGEE

In these cases the insurance policy is a contract between the insurance company and the mortgagor. The mortgagee seldom pays the premium and does not appear in the policy as a contracting party. There is a rider, or a special mortgagee clause in the policy, providing that the loss is to be paid to the mortgagee. That is, he is one of the two persons for whose benefit the contract is made, and he is a creditor of the mortgagor (the promisee). Can he maintain an action against the insurance company? Has he any "rights" against the insurer, created by the contract? 
Massachusetts has been able to sustain the mortgagee's action on the theory that he is the promisee. ${ }^{34}$ This is fiction and not fact, as the Connecticut court has at least twice held. In Woodbury Savings Bank v. Charter Oak Ins. Co., ${ }^{35}$ the bank as mortgagee brought suit on a policy containing the words, "payable in case of loss to the Woodbury Savings Bank." It offered parol testimony to show that it was in fact the promisee and a party to the contract. The court held that this evidence was not admissible, by reason of the parol evidence rule. Such evidence would vary the writing, in which it appeared that the mortgagor was the party to the contract. Had the bank frankly sued as a mere beneficiary in an action of assumpsit, no doubt it would also have lost; but it ought to get practically identical relief by phrasing its complaint in terms of equity and making the mortgagor a co-defendant. An assignment obtained from the mortgagor would entirely obviate any difficulty as to the form of action.

In Meriden Savings Bank v. Home Ins. Co., ${ }^{36}$ the mortgagee bank was given judgment against the insurer; but the court made use of a subterfuge. There was a collateral sealed agreement between the insurance company and the mortgagee, providing that certain enumerated acts of the mortgagor should not invalidate the policy as against the mortgagee. For this reason, even though the mortgagee could not sue on the policy alone, and even though neither the policy nor the collateral contract contained a promise to the mortgagee to pay him, the court proceeded to hold that there was privity and that the mortgagee could maintain suit on the two documents together. It seems clear that the court was willing to give a broader effect to the collateral contract between the mortgagee and the defendant than the parties intended, in order to carry out the actual intention of the mortgagor and the defendant as expressed in the policy. The court further said that it made no difference that the defendant might be liable to two suits, inasmuch as it had made two contracts with two parties. But it may be observed that these two contracts called for only one performance.

Twenty three years later, in Collinsville Sav. Soc. v. Boston Ins. Co., ${ }^{37}$ the court permitted the mortgagee to maintain suit on the policy, but here he had taken the precaution to get an assignment from the mortgagor. Of this assignment, however, Judge Prentice said that by it the plaintiff had not "acquired any right which it did not previously have, save the right to maintain in its own name an action against the defendant." He further said that the mortgagee clauses did not create privity between the mortgagee and the insurer, that the mortgagee was not the "insured," and that he was "only an appointee of the owner as

"Palmer Savings Bank v. Inusurance Co. (1896) I66 Mass. I89, 44 N. E. 2 rr.

35 (I860) 29 Conn. 374.

so (1882) 50 Conn. 396.

87 (1905) 77 Conn. 676, 60 At1. 647. 
respects whatever may become due under the contract of insurance to which he is a stranger." He said also, however, that upon the happening of a loss "the mortgagee acquires a vested right," and held that the character of this right was measured by the terms of the policy.

We thus see arising a multitude of cases where third parties are pressing upon the courts to enforce rights created by contracts made by others. The supposed requirement of privity does not seem to be present in the consciousness of these persons. Their cases are of many sorts. Mortgagees rely upon policies made for their benefit; creditors try to force payment by promisors who have assumed the debt; laborers and material men rely on surety bonds given to another for their benefit; actions are brought by injured parties on official bonds. ${ }^{38}$ And in one way or another the Connecticut courts have been able in most cases to gratify these plaintiffs. New cases have a most uncomfortable way of playing havoc with revered general rules. Privity is required as a general rule, says the court; but of what force is a general rule when it is opposed by currently accepted practices and notions of justice, by the "settled convictions of the community," by the "established and settled judgment of society," 39 by the mores of the time! $!^{40}$ A general rule is tough, even under these circumstances; it dies hard. But those busy little microbes known as exceptions and distinctions gradually weaken its constitution so that it is eventually slain by the giant known as Weight of Authority; and then nothing is left but a bag of bones to weight down the backs of subsequent legal investigators.

\footnotetext{
${ }^{3}$ Statutes requiring official bonds and giving various remedies are Gen. Sts. I9I 8 , secs. $206,217,5221,5222$. The state or other obligee in such a bond may have an interest making it a necessary party. In Baker v. Baldzein (I880) 48 Conn. I3I, the'State Treasurer as obligee brought debt on a sheriff's bond, no doubt holding the sum recovered, in part at least, as trustee for the judgment creditor who had been injured. In Tozen of Norwalk, ex rel. Fawcett, v. Ireland (I896) 68 Conn. I, 35 Atl. 804, an action on a constable's bond for wrongful seizure, Fawcett is referred to as "plaintiff," and the Town of Norwalk (the obligee) is not referred to in the opinion. See also National Roofing Tile Co. v. Macdonald (I9I9) 94 Conn. 240, I08 Atl. 726, allowing the claim of a beneficiary against a surety company resting on Missouri law.
}

${ }^{3}$ Wheeler, J., in Dwy v. Connecticut Co. (1915) 89 Conn. 74, 92 Atl. 883.

${ }^{40}$ As expounded by William G. Sumner, Folkzways (1906). 